EPRA International Journal of Economic and Business Review-Peer Reviewed Journal

Volume - 9, Issue - 8, August 2021 | e-ISSN: 2347 - 9671| p- ISSN: 2349 - 0187

\title{
A STUDY OF IMPACT OF PSYCHOLOGICAL BIASES ON INVESTOR'S INVESTMENT DECISION
}

\author{
Vijaya A. Tupe \\ Research Student, Dept. of Management Science, Dr. Babasaheb Ambedkar Marathwada University, \\ Aurangabad, Maharashtra, India.
}

\begin{abstract}
DOI No: 10.36713/epra8324

Article DOI URL: https://doi.org/10.36713/epra8324

The paper examines the impact of psychological biases on investor decisions Investors always make rational decision. He or she collect information about investment and while analyzing investment decision various psychological factors effect on investor's investment decision. However, investor also influenced by various psychological bias and investor personalities that effect on investment decision. Behavioural finance studies that investor spend time on investment decision while that time he or she influenced by biases. The aim of this paper is to evaluate impact of behavioural factors on investment decision made by investors in Aurangabad city.
\end{abstract}

KEYWORDS: Behavioural Finance, Behavioural Investor types, Psychological Bias.

\section{INTRODUCTION}

Behavioural finance is a concept developed with field of psychology and finance. The concept not only just a part of finance but also it broader and wider scope includes multidisciplinary from finance, psychology, sociology, social-psychology, economics, behavioural economic, investing and behavioural accounting (Shuchita Singh and Shilpa Bahi, 2015). 


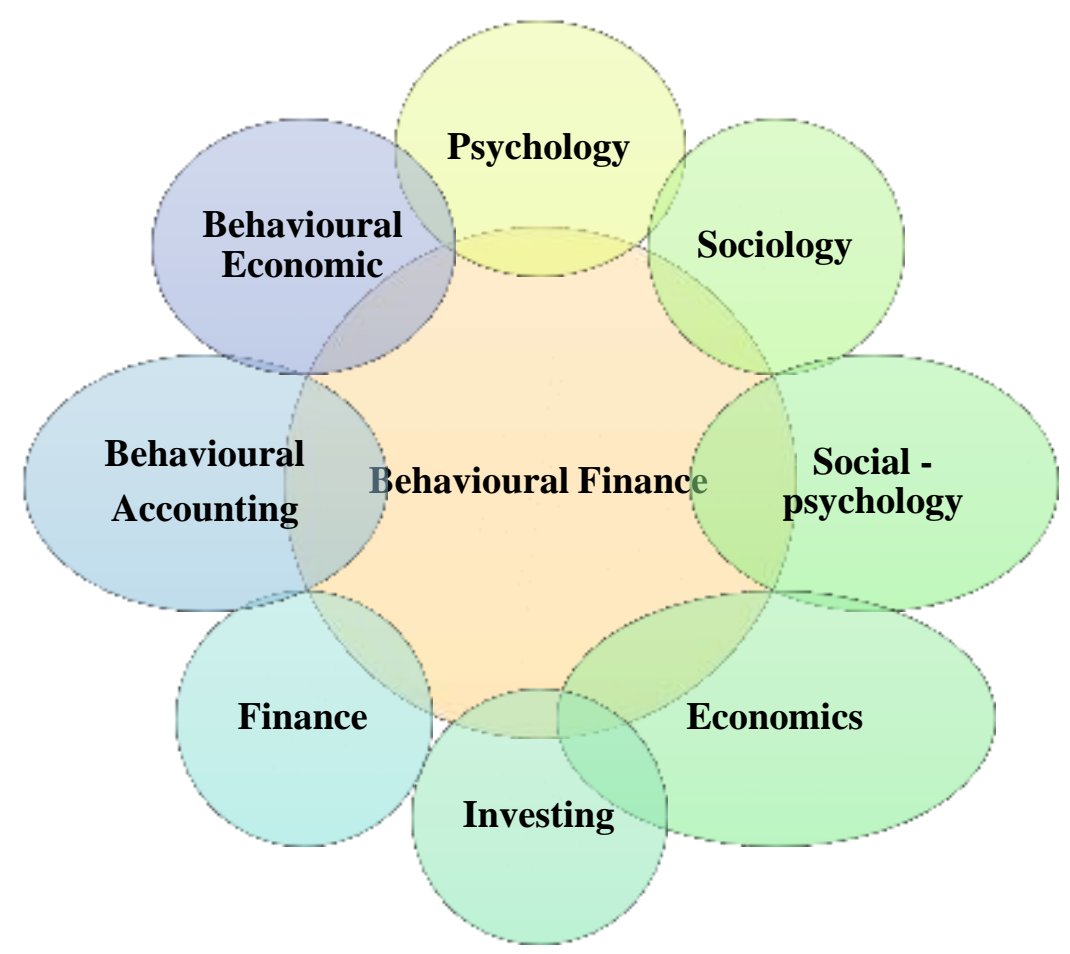

Fig.-1: Factors of Behavioural Finance

\section{INVESTOR}

Investment behavior is defined investors judge, predict, analyze and review about decision making, it reflect investment psychology, information gathering, defining and understanding, research and analysis (Slovic, 1972). Human beings are known to make decisions based on their knowledge and feeling rather than collecting sufficient information which will facilitate effective decision making. Some behavioral economist study emotional and psychological factors and their impact on investment decision making. Investment decisions in everyday life depend on combination of different factors like, emotion, reason, habit and social interaction (Chaudhary, A. K. (2013).

\subsection{PSYCHOGRAPHIC MODELS OF INVESTOR BEHAVIOR}

Two models of investors or personality traits into two types:

a. Active investors

"Active investors" are individuals who have been actively involved in wealth creation through selfproperties investment, and they want taken risk on their own capital and preserve wealth objectives. Active investors have a higher tolerance for risk than they have need for security.

\section{b. Passive investors}

"Passive investors" are defined as those investors who have become wealthy passively passive investor wants more securities and able to risk tolerance but this type investor taking more risk on other funds (Barnewall 1987). 
SJIF Impact Factor (2021):8.302 || DOI: 10.36713/epra2012 | Volume-9 | Issue-8 | August 2021 | e- ISSN: 2347-9671 | p- ISSN: 2349-0187

Table: 2 Behavioral Investor Types (BIT) \& Investor's psychological Bias

\begin{tabular}{|c|c|c|c|c|}
\hline General type & \multicolumn{2}{|c|}{ Passive } & \multicolumn{2}{|c|}{ Active } \\
\hline $\begin{array}{l}\text { Risk Margin of } \\
\text { investor }\end{array}$ & $\begin{array}{c}\text { Conservative } \\
\text { (Low) }\end{array}$ & $\begin{array}{c}\text { Moderate } \\
\text { (Low to medium) }\end{array}$ & Aggressive & Growth \\
\hline BIT & $\begin{array}{l}\text { Preserver } \\
\text { (safe) }\end{array}$ & $\begin{array}{l}\text { Follower } \\
\text { (Moderate) }\end{array}$ & $\begin{array}{c}\text { Accumulator } \\
\text { (Confident) }\end{array}$ & $\begin{array}{c}\text { Independent } \\
\text { (Risk) }\end{array}$ \\
\hline Biases & $\begin{array}{c}\text { Status Quo } \\
\text { Endowment } \\
\text { Loss aversion } \\
\text { Mental accounting } \\
\text { Anchoring }\end{array}$ & $\begin{array}{c}\text { Regret } \\
\text { Outcome } \\
\text { Cognitive } \\
\text { Dissonance } \\
\text { Hindsight } \\
\text { Framing } \\
\text { Recency }\end{array}$ & $\begin{array}{c}\text { Affinity } \\
\text { Overconfidence } \\
\text { Self - Control } \\
\text { Illusion of Control }\end{array}$ & $\begin{array}{c}\text { Conservatism } \\
\text { Availability } \\
\text { Confirmation } \\
\text { Representativeness } \\
\text { Self - Attribution }\end{array}$ \\
\hline
\end{tabular}

The Behavioral Investor Types are framework of clients (investors). Michael Pompian studied behavioral finance in that research he identified 20 behavioral biases. He noted that certain type of investors involve certain biases.

\subsection{Following are types of behavioral investor types: \\ a. Preserver \\ b. Follower \\ c. Independent \\ d. Accumulator}

\section{a. PRESERVER}

Basic type: Passive - Risk tolerance level: Low Primary bias: Emotional

Preserver is passive investors don't want any risk on their own capital. They depended only professional job earn and runaway from risk factor. Preserver collect funding for family members security need like, education, health, home buying. Preserver behavioral biases carried emotional as well as cognitive biases.

- Loss Aversion Bias

Preservers tend to feel the pain or avoid losses more than the pleasure of gains as compared to other client types. Investors are more sensitive to loss than to risk and potential return.

- Endowment Bias

Preservers are inherit or genetic wealth, and an investment. They already own such as a piece of real estate or stocks etc. investor tried investment and had the potential to develop or acquire it.

- Anchoring Bias

Anchoring bias is a phenomenon in which in the absence of better information, investors assume current prices are about right People tend to give too much weight to recent experience recent trends .

- Mental Accounting Bias
Mental accounting refers to the coding, categorization, and evaluation of financial decisions. For example, Preservers secure their assets into safe "buckets." all assets are viewed as safe money.

- $\quad$ Status Quo Bias

Preservers prefer to keep their investments safely and stable (and other parts of their life for that matter) the same level or "status quo."

\section{b. FOLLOWER}

Basic type: Passive - Risk tolerance level: Low to medium- Primary bias: Cognitive

Followers are passive investors who don't have their own idea about investment. They are following their family and friends opinion. Followers generally adopt professional advices when they get it.

- Recency Bias

Recency bias examined human memory recall and testing. It is predisposition for investors to recall and emphasize recent event or observation.

- Hindsight Bias

Followers often lack independent thought about investment and sensitive bias. They make only predication the outcomes of investment.

- Framing Bias

Framing bias is the tendency if followers to respond to situation differently as per frame context. Investors focus on one or two aspect of situation.

- Cognitive Dissonance Bias

Psychology study cognitions represent attitude, emotions, beliefs or values. In this bias investors satisfy with first decision but afterword they do compare another second situation to first one.

- Regret Aversion Bias

Regret aversion bias investor fear about risk on investment. Because investor to be timid in their investment choices because old losses experienced. 


\section{c. INDEPENDENT}

Basic type: Active - Risk tolerance: Medium to high Primary bias: Cognitive

These investors have been actively involved in their wealth creation. Specially risk their own capital in achieving their wealth objectives.

- Conservatism Bias

Conservatism bias is a mental process in which people stick to their previous view or old information investment decision.

\section{- Availability Bias}

Investors will chose investment based in information that available to them (advertising, suggestion from advisors, friends, and family) will not engage in disciplined research.

- Representativeness Bias

Representativeness bias makes always new information and think only present idea on existing data investment by newly pattern.

- Self-Attribution (Self-Enhancing) Bias

Self-attribution bias is independent investor. The individuals have a tendency to attribute success to own their skills.

- Confirmation Bias

Confirmation bias occurs when people observe, actively seek out information and confirm it.

\section{d. ACCUMUlator}

Basic type: Active - Risk tolerance: High Primary bias: Emotional

Accumulator is active investor who has actively part their own capital wealth creation and risking their own capital.

\section{- Overconfidence Bias}

This bias strongly faith own thoughts and abilities of investors.

\section{- $\quad$ Self-Control Bias}

This bias is the tendency to investor today at the expenses of saving tomorrow. They think less for future retirement investment.

\section{- Affinity Bias}

Affinity bias refers to an individual's tendency to make irrationally uneconomical consumer choices or investment decision based in self believe.

\section{- Illusion of Control Bias}

Illusion of control bias occurs when investor believe that they can control influence investment.

\section{- Outcome Bias}

Investor decide to do something like make an investment experience. They are observing process information about decision makers.

\section{METHODOLOGY}

\section{Review of Literature}

1. Kahneman \& Tversky, (1979); Tversky \& Kahneman, (1974) Cognitive biases can result from the reliance on heuristics that help people to make judgments in face of uncertainty. It's worth noting that psychological behavioural biases were first identified by Tversky and Kahneman in (1974.)

2. "Psychology and Financial Decision Making “ late Herbert Simon, $\mathrm{PhD}$ in Political Science, Professor of Psychology at Carnegie-Mellon University in (1978) Nobel laureate in economics has given the very important concept of 'bounded rationality'.

3. Two psychologists Kahneman and Tversky (1979), also conducted researches on cognition investors, and found that investor's cognitive biases, feelings and attitudes increases by the time and form beliefs and preferences those considered errors in decision-making.

4. Linter (1998) has defined behavioural finance as study of how human interprets and act on information to make informed investment decisions.

5. Behavioural biases have been attributed to the irrationality in decision making (Shefrin According to Graham et al (2002) the field of behavioural finance is focused on the psychological factors that lead to common investment practices.

6. Shefrin (2000) indicated that when psychological aspects affect the decision making process of financial practitioners, it is the study of behavioural finance.

7. Baker \& Nofsinger, (2002); Barber \& Odean, (2001); Kahneman \& Riepe, (1998); Shefrin, (2002). The individual investors are prone to various biases that prevent them from making sound investment decisions.

8. Baker \& Nofsinger, (2002) Study examined on psychological bias and emotion to affect their investment decisions, investors can do serious harm to their wealth".

9. Kahneman and Smith (2002) discussed the relationship between financial economics and psychological decision making and coined the term behavioural finance.

10. Gilovich and Griffin (2002) opined that behavioural finance is basically behavioural economics where investors take economic decisions irrationally when they apply emotional appeals to decide their transactions related with spending, borrowing and investing.

11. According to Baker and Nofsinger (2002), the difference between traditional and behavioural 
finance is an issue of how each discipline is developed.

12. Frankfurter and McGoun,(2002) described -Behavioural finance, as a part of behavioural economics, is that branch of finance that, with the help of theories from other behavioural sciences, particularly psychology and sociology, tries to discover and explain phenomena inconsistent with the paradigm of expected utility of wealth and narrowly defined rational behaviour. Behavioural economics is mostly experimental, using research methods that are rarely applied in the traditional, mainstream finance literature.

13. Ritter(2003). In this context, studies have examined the effect of cognitive and arbitrage limits on investment decisions with varied results.

14. Brown \& Reill (2004) Behavioural finance seeks to understand and predict systematic financial market implications of psychological decision processes. Behavioural finance considers how various psychological traits affect how individuals or groups act as investors, analysts, and portfolio manager's literature clearly supports the fact that behavioural biases have impact on investment decision making.

15. Hatfield and Horvath (2005) used the MyersBriggs Type Indicator to assess risk tolerance differences between people with different personality characteristics.

16. Pompian (2006) that claimed about behavioural biases has relationship with investor's type. The different investors show different behavioural biases. It is also observes that different investors make financial decision differently.

17. Shefrin 2000; Pompian (2006) Standard Finance Models are based on rationality which implies two things i.e. people update their belief.

18. According to Bodie et al. (2008) Behavioural economist opposes this concept of perfect rationality and study emotional and psychological factors and their impact on investment decision making. Investment decisions in everyday life depend on combination of different factors like, emotion, reason, habit and social interaction.

19. Chandran (2008) the study concluded that behavioural factors and their impact on investors' attitude towards risk and behavioural decision making process. The individual investors suffer from heuristics such as representativeness, overconfidence and anchoring, cognitive dissonance, greed and fear, and regret aversion and mental According to Suresh (2013) understanding various behavioural key biases and traits can help individual take sound financial decisions and in turn make him a better trader/investor.
20. The irrational financial decisions of investors in the domain of behavioural finance. He found that emotional and cognitive factors have a strong impact on investors' decision making process. Some of the factors that affect investor's decision making process are loss aversion, overconfidence, anchoring, over and under reaction and herd behavior (Chaudhary, 2013).

21. De Bondta et al. (2013) studies emotional and psychological factors and their impact on investment decision making. Investment decisions in everyday life depend on combination of different factors like, emotion, reason, habit and social interaction.

22. Dr. Babaraju K. Bhatt, Ms. Apurva A. Chauhan (2014) The Behavioural finance they identified various behavioural factors influencing the decision of investor in stock market. It is a new paradigm of finance which seeks to supplement the modern theories of finance by introducing behavioural aspect to provide explanation for why investors make irrational decision.

23. Chaffai \& Medhioub (2014) study in Tunisia found that small investor's investment decisions depends on their behavioural biases and market efficiency.

24. accounting all influence investor's perception of risk and subsequently his decision making.

25. Rajarajan (2000) endeavored to discover predictors of individual investors' expected rate of return by examining connection of demographic variables such as age, income, occupation, service status and phase in life cycle with investment behaviour of a person. The study inspected the association between expected rate of return on investments by individual investors and their characteristics.

\section{CONCLUSION}

This study is attempted to determine the role of behavioral biases in investment decision and its investor's types. The Findings from study will help to identify the impact of behavioral biases.

\section{REFERENCES}

1. Adam, S. (2010). Behavioral Anatomy of the Financial Crisis. Journal of Centrum Cathodra 3(2), 121-135.

2. Bahi,b.s (2015). Behavioural finance,vikas publishing.

3. Barber, B. M. and Odean, T. (2001) Boys Will Be Boys: Gender, Overconfidence, and Common Stock Investment, The Quarterly Journal of Economics, 116, $261-292$.

4. Barberis, N., \& Thaler, R. (2003). A survey of behavioral finance. Handbook of the Economics of Finance, 1, 1053-1128. 
5. Barnewall,M.M.(1987) Behavioural investor types diagnostic process.

6. Chaffai, M., \& Medhioub, I. (2014). Behavioral Finance: An Empirical Study of the Tunisian Stock Market. International Journal of Economics and Financial Issues, 4(3), 527-538.

7. Chaudhary, A. K. (2013). Impact of Behavioral Finance in Investment Decision and Strategies-A Fresh Approach. International Journal of Management Research and Business Strategy, 2 (2), 85-92.

8. Chaudhary, A. K. (2013). Impact of Behavioral Finance in Investment Decision and Strategies-A Fresh Approach. International Journal of Management Research and Business Strategy, 2 (2), 85-92

9. Daniel Kahneman and Amos Tversky, "Prospect Theory: An Analysis of Decision under Risk," Econometrica 47 (1979): 263-91.

10. DR. BABARAJU K. BHATT1, MS. APURVA A. CHAUHAN(2014) Volume 3, Issue 2, February 2014 ISSN 2319 - 4847International Journal of Application or Innovation in Engineering \& Management (IJAIEM) Web Site: www.ijaiem.org Email: editor@ijaiem.org,editorijaiem@gmail.com

11. Dr. Ravi Vyas (2012), "Mutual Fund Investor's Behaviour and preception in Indore city." Vol. - III, Issue-3(1) Geetika Madaan Sukheja 2016" Behavioral Biases In Financial Decision Making”

12. http://shodhanga.Behavioural Finance and review of literature

http://shodhganga.inflibnet.ac.in/bitstream/10603/12 706/10/10_chapter\%202.pdf

13. Imran Umer Chhaprra, Muhammad Kashifa, raja Rahanb,Ashow Baia. (2018, Aprial 2). An empirical investigation of investor's behavioural biases on financial decision making. Asian Journal of Empirical Research, $8(3$ (2018) : 99-109), 1-2. doi: 10.18488/journal.1007/2018.7.3/1007.3.99.109

14. M. Barnewall, "Psychological Characteristics of the Individual Investor," in Asset Allocation for the Individual Investor, ed. William Droms (Charlottesville, VA: Institute of Chartered Financial Analysts, 1987).

15. M.pompian. (2006). Behavioral finance and wealth management. John Wiley \& Sons.

16. Pompian, M., \& Longo, J. (2005). Incorporating behavioral finance into your practice. Journal of Financial Planning, 18(3), 58-63

17. Pompian, M., \& Longo, J. (2005). Incorporating behavioral finance into your practice. Journal of Financial Planning, 18(3), 58-63

18. Sahi, S. K., \& Arora, A. P. (2012). Individual investor biases: A segmentation analysis. Qualitative Research in Financial Markets, 4(1), 6-25. Sahi, S. K., Dhameja, N., \& Arora, A. P. (2012).

19. Shefrin, H. (2000) Beyond Greed and FearUnderstanding Behavioral Finance and the Psychology of Investing. Harvard Business School Press, Boston, Massachusetts.
20. Shiller, R. J.(1990) Speculative Prices and Popular Models, Journal of Economic Perspectives, 4(2), 54 66

21. Shuchita Singh \& Shilpa Bahi 2015, Behavioural Finance, Vikas publication house,ISBN: 978-932598457-8

22. Slovic, P. (1972). Psychological study of human judgment: Implications for investment decision making. The Journal of Finance, 27(4), 779-799. Soros, $G$.

23. T. bailard,D.biehl and R.kaiser. (1986). BIT. personal money management, 4.

24. T. C. THOMASa* AND G. RAJENDRAN ()" BB\&K Five-way Model and Investment Behavior of Individual Investors: Evidence from India" Int. Journal of Economics and Management ISSN 1823 $836 X$

25. Thomas Bailard, David Biehl, and Ronald Kaiser, Personal Money Management, 5th ed. (Chicago: Science Research Associates, 1986). 4. M. Barnewall, "Psychological Characteristics," see note 2. 5. T. Bailard, D. Biehl, and R. Kaiser, Personal Money Management, 